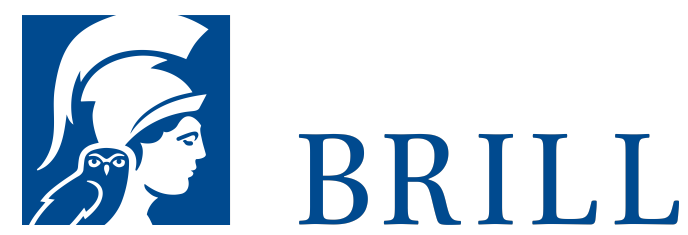

\title{
The Protection against Unfair Competition in the WTO TRIPS Agreement
}

The Scope and Prospects of Article 1obis of the Paris Convention for the Protection of Industrial Property

Author: Christian Riffel

In The Protection Against Unfair Competition in the WTO TRIPS Agreement, Christian Riffel offers an account of the potential which Article 1obis of the Paris Convention has for the world trading system. In particular, the author explores what hard law obligations emerge and examines a possible application to unsettled issues, such as core labour standards and traditional knowledge.

Article 1obis embodies unfair competition law in a nutshell. The TRIPS Agreement incorporates this Article into the World Trade Organization, thus making unfair competition law a discipline of international trade law. By providing an effective enforcement mechanism against unfair competition, the WTO upholds 'honest practices' in the course of trade, alleviating enforcement deficits in other areas of international law.

Readership

All interested in international trade, competition and IP law, and anyone concerned with indigenous issues and labour rights.

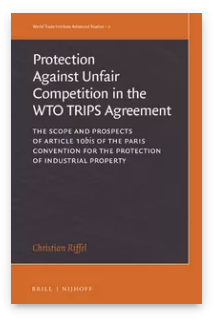

Language:

English

Subjects:

International

Commercial,

Trade \&

Investment Law,

International

Law,

International

Law: General

Interest,

International

Law

Publisher: Brill |

Nijhoff

Series:

World Trade

Institute

Advanced

Studies, Volume:

2

E-Book (PDF)

Released online:

10 Jun 2016

ISBN: 978-90-

04-31347-7

List price

USD $\$ 206.00$

Hardback

Publication date:

23 Jun 2016 
ISBN: $978-90-$

Christian Riffel, Ph.D. (2014), University of Bern, is a lecturer in 04-31348-4 List price law at the University of Canterbury, New Zealand, and CoDirector of the Master of Laws (LLM) in International Law and Politics. He is one of the primary contributors to the Max Planck Encyclopedia of Public International Law and Assistant Editor of the New Zealand Yearbook of International Law.

For more information see brill.com

Order information: Order online at brill.com +44330 333 oo49 | customerservices@brill.com Submission information: brill.com/authors

Titles published by Brill | Fink, Brill | mentis or Brill | Schöningh: +49(o)71 5413279216 | brill@brocom.de 